\title{
The Association between Social Capital and Voting Participation in Three Developing Democracies in Africa
}

\author{
Jack Chola Bwalya ${ }^{1} \&$ Prasanth Sukumar ${ }^{2}$ \\ ${ }^{1}$ School of Politics and International Relations, University College Dublin, Ireland \\ ${ }^{2}$ School of Medicine, University College Dublin, Ireland \\ Correspondence: Dr Jack Chola Bwalya, School of Politics and International Relations, University College \\ Dublin, Ireland. Tel: 35-38-7747-7192. E-mail: jack.bwalya@ucdconnect.ie
}

Received: November 1, 2017

Accepted: November 17, 2017

Online Published: February 4, 2018

doi:10.5539/jpl.v11n1p42

URL: https://doi.org/10.5539/jpl.v11n1p42

\begin{abstract}
Numerous empirical research studies posit that social capital has a positive influence on peoples' political participation. Studies conducted in developed western democracies have revealed that social capital strengthens democratic institutions by impacting both the quantity and quality of citizens' political participation. However, in the developing democracies of Africa, the effects of social capital on political participation remain under-researched. This paper aims to empirically examine whether the interrelation between social capital and political participation holds true in the developing democracies of Africa. By operationalising the concept of social capital as membership in civic associations, this paper examines the influence of social capital on peoples' voting participation in three Southern African countries, viz. Botswana, Namibia and Zambia. Using data from the sixth round of the Afrobarometer Survey, this study found that social capital was strongly linked to voting participation in these countries.
\end{abstract}

Keywords: Africa, social capital, voting-participation, Botswana, Namibia, Zambia

\section{Introduction}

In his 1993 classic study, "Making Democracy Work", Robert Putnam (1993) demonstrated that social capital has a direct effect on political participation. By studying the Italian civic traditions, Putnam could link the performance of regional governments to the historical legacies of community participation in social organisations. Putnam's main argument is that the more people participate in civic associations, better the government, the consequence of which is the improvement of the effectiveness of democratic institutions (Putnam et al., 1993, p. 182). He points to the fact that the more people engage in civic organisations, the more they develop the sense of belonging; this, in turn, establishes a level of interpersonal trust and consequently creates a willingness to engage in collective action for the betterment of the group. Putnam, therefore, sees the characteristics of civic associations such as norms, trust and social cohesion as the community's stock of social capital, which can be relied on for political action and community well-being (Putnam et al., 1993, p. 175).

Since Putnam's work, several studies in other societies have confirmed that social capital and political participation have an interdependent relationship (Miller, 2001; Norris, 2002; Putnam et al., 1993; Verba, Schlozman, \& Brady, 1995). In the advanced democracies of the Western world, a number of researchers have found that social capital helps to maintain the development of democracy by influencing both the quantity and quality of political participation (Anderson, 2010; Fukuyama, 1995; Mayer, 2003; Moyser \& Parry, 1997; Norris, 2002; Paxton, 2002; Putnam, 2001).

However, the effect of social capital on political participation has not been clearly explored in the developing democracies of Africa. This article intends to address this gap by examining to what extent social capital influences voting participation in three developing democracies in Africa, viz. Botswana, Namibia, and Zambia. Using data from the sixth round of the Afrobarometer survey and measuring social capital as membership in civic organisations, we examine the influence of social capital on voting participation.

\section{Social Capital and Its Relationship with Political Participation}

Many contemporary scholars have contributed significantly to the discourse around the meaning of social capital; Pierre Bourdieu (1986) and Robert Putnam (Putnam, 1995a, 1995b, 2001; Putnam et al., 1993) are prominent 
among them. For Bourdieu, social capital is an individual resource which can be produced and reproduced within a given social grouping. Bourdieu contends that the production and reproduction of an individual's social capital is dependent upon the size of the social networks that a person can efficiently mobilise, as well as the volume of various forms of capital such as cultural, economic, education or symbolic that a person possesses relative to all other members in a given social network (Bourdieu, 1986, p. 249). Bourdieu's main emphasis is on the privileges which those with social capital can afford. For example, by virtue of belonging to a certain social group, an individual could gain access to certain things in life through the direct or indirect application of their social connections.

Putnam, on the other hand, sees social capital not as the possession of an individual person, but rather as a "collective value of all social networks" through which citizens from all strata of life participate with social trust in civic organisations and "community affairs" (Putnam, 1995b, p. 664). He argues that through these actions, individuals become active members of society and this naturally creates a knowledge of others and thus a willingness to cooperate with each other (Putnam, 1995b). This, Putnam argues, is a critical element for enabling political participation and strengthening democracy (Putnam, 2001; Putnam et al., 1993, pp. 6-7). According to Putnam, this increases the likelihood that those who are members of civic organisations will participate in everyday politics more than those who are non-members. For the present study, we appropriate Putnam's concept of social capital in order to answer the question as to what extent social capital influences voting participation in three developing democracies in Africa.

Other scholars including Coleman (1988) and Portes (1998) have also contributed a great deal to the concept of social capital. It appears now that there is a consensus in the literature that social capital generally affords participants in social networks the ability to accrue some benefits as a result of being members of those social networks.

\subsection{Regional Evidence}

It has been argued for a long time that there is a strong correlation between engagement in civic organisations and political participation (Ayala, 2016; Putnam, 2001; Verba et al., 1995). Most recent studies have shown this relationship to hold in most developed democracies including the United States of America (USA), Western Europe and Great Britain (Moyser \& Parry, 1997; Stolle, 1998; Stolle \& Rochon, 2016). For an analysis of this relationship in other European countries, see Hooghe \& Marien (2013).

A number of studies in Central America have also found a correlation between social capital and political participation (Anderson, 2010; Booth \& Richard, 1998; Klesner, 2007). For example, in a 1999 study on the role of organisational involvement in political participation in Central America, Seligson (1999) used survey samples drawn from all the Spanish-speaking countries in South America and revealed a positive correlation between social capital and political participation.

A similar relationship has also been found in some Asian countries. For example, in India, social capital has been found to positively influence political participation as well as public decision-making processes. In a study of 69 village communities in the two north Indian states of Rajasthan and Madhya Pradesh, Krishna (2016) discovered that social capital was a key variable in supporting political participation. In their 2007 study in South Korea, Lee \& Glasure (2007) examined the second and third waves of the World Values Surveys and found that there was "...a sharp rise in the percentage of civic engagement over a six-year period between 1990 and 1996..." and this, in turn, had a positive effect on political participation in that country.

To our knowledge, no studies in Africa to date have specifically looked into the relationship between social capital and political participation. However, there are studies which have explored the role of social capital in other aspects of political engagement and found that the effect is not consistent. For example, Widner \& Mundt's (1998) study considered the effect of membership in civic organisations on state-building in African countries like Botswana and Uganda. Their study found a weak relationship between social capital and governmental effectiveness in Botswana and Uganda. In another study using Afrobarometer data, Kuenzi (2008) examined the influence of social capital and political trust in Nigeria and Ghana. It was found that organisational membership has a negative association with political trust in Nigeria and a weak positive relationship in Ghana.

While exploring the relationship between social capital and political violence in Africa, Bhavnani \& Backer (2007) found that "...membership in professional and business associations is consistently linked with greater levels of political violence, whereas membership in religious groups seems to lessen such conflict" (p. 2). Furthermore, other studies in African countries have explored the influence of social capital on other aspects of social life in Africa. For example, in a 2004 study using property rights as an indicator of social capital, Addison \& Baliamoune-Lutz (2004) explored the role of social capital in post-conflict reconstruction in Africa and found 
that social capital has played an important role. In a 2001 study, Fafchamps \& Minten (2001) found that in Benin, Malawi and Madagascar, traders who possessed more contacts with other traders had higher trader output. These studies provide empirical support to the effect of social capital on different aspects of life including economic growth and development in Africa.

\subsection{Social Capital and Voting Participation}

According to Verba et al., (1995) when people are involved in civic organisations, the chances of them getting involved in politics also increases. Studies by Putnam (2001), Rotemberg (2009), Edlin et al. (2007), LeRoux \& Krawczyk (2014), Berinsky (2016) and Fowler (2006) have also shown that being a member of a civic organisation increases the likelihood of political participation.

Studies (Putnam, 1995b, 2001; Putnam et al., 1993; Stolle, 1998) have shown that areas with higher measures of social capital/civic organisation membership tend to report higher voter turnout. One of the suggested reasons for higher turnout has been peer-influence. Members might inform others of the benefits of voting and those who may not want to go out and vote could possibly be forced to go because of social pressure or fear of social sanctions. According to Gerber et al., (2008) social pressure contributes significantly to voter turnout. In an experiment carried out in a low-salience primary election in the USA, it was found that when participants were threatened by the researchers that their neighbours would be informed whether or not they voted in the election, turnout to the polls increased from $30 \%$ to $38 \%$ (Gerber et al., 2008).

Also, according to Berinsky (2016) and Fiorina (1990) sharing and increasing the flow of political information within a community can increase voter turnout. Other scholars, including Stolle (1998), have argued that well-coordinated and functioning communities can easily enforce collective behaviour among their members such as political participation. Fowler (2005) and La Due Lake \& Huckfieldt (1998) assert that membership in civic organisations and the resulting social connectedness encourage individuals to go out and vote during elections (see also Nygård, Nyqvist, Steenbeek, \& Jakobsson, 2015). Other studies have pointed out that the size of the community also matters in terms of voter turnout. If the size of the community is small and cohesiveness within the community is high, voter turnout has been found to be high; especially if the elections that are taking place are very decisive and important. One of the suggested reasons for this is that social pressure on members within small communities might be high in order to involve them in civic duties, while their nonparticipation could result in loss of social prestige or reputation (Blais, 2006; Geys, 2006).

Although many studies have shown a positive relationship between social capital and political participation, there is also evidence that social capital may sometimes undermine political participation. For example, Mutz (2002) suggests that social connectedness resulting from membership of civic organisations tends to decrease voter turnout, especially when individuals are receiving conflicting political arguments from their network. Mutz asserts that when individuals are exposed to conflicting political views, their willingness to participate in political activities might be lessened.

According to a classic study by Riker \& Ordeshook (1968), individuals taking part in different forms of community activities might feel that they have already participated sufficiently in community life and so feel less interested in voting. Participation in other forms of community activities thus makes some members of the community unwilling to go out and vote, consequently decreasing voter turnout. On this distinction, scholars such as Atkinson \& Fowler (2014) assert that an "exogenous increase in community activity actually decreases voter turnout" (p. 44).

Set against that background, this paper focuses on Putnam's conceptualization of social capital and examines how it may influence peoples' political participation in Africa. Our aim is to see whether there is any relationship between participation in civic organisations and voting participation in three democratically advancing countries in Southern Africa, namely Botswana, Namibia and Zambia.

\section{Method}

This section explains the case selection criteria and statistical analysis employed in this study.

\subsection{Case Selection: Botswana, Namibia and Zambia}

To investigate the relationship between social capital and voting participation in Africa, we have chosen three countries, Botswana, Namibia and Zambia, for the following reasons. Firstly, these three countries are seen as the best models of successful democratisation in the Southern African region (see e.g. Düsing (2002) for an analysis on Botswana and Namibia as shining examples of democracy in Southern Africa). Secondly, these are neighbouring countries, sharing borders and having similar geographical as well as socio-cultural intricacies, so they are ideal for the purpose of comparison (Friede \& Steel, 1986; Lewis, 2010; Taylor, 2006). 
Botswana is considered a relatively stable democracy in Africa (Goldsmith, 2001; Lindberg, 2005). Since its independence from Great Britain in 1966, Botswana has held several successful elections which were endorsed by the international community as free and fair (e.g. see Jager, 2014). Similarly, Zambia is the first country in the Southern African region to have adopted the multiparty democratic system after independence from Great Britain in 1964. Other than being forced to be a single-party political system during 1973-1990, Zambia has been holding relatively free and fair multi-party elections since independence. Zambia has now been seen by the international community as one of Africa's democratic success stories (on this distinction, see J. C. Bwalya, 2017). Despite being the youngest democracy among the three countries chosen for this study, Namibia has been holding multi-party elections since its independence from Germany in 1990. As a result, Namibia's democratic credentials rank among the best in the whole of Africa (for Botswana, Namibia and Zambia's democratic status, see the website Freedomhouse.org).

Along with the advancement of democracy in Botswana, Namibia and Zambia, many civil society and non-governmental organisations have started to blossom, providing the citizens of these countries with the opportunity to participate more easily in community activities. This is in stark contrast to the colonial period when freedom to participate in civic organisations was severely restricted. Because of the growing number of civic organisations in Africa, people can now openly participate in civic activities and express their opinions freely (Bartlett, 2000). The increasing possibility of participation in community and civic organisations could, in turn, influence their participation in political activities. Using data from the Afrobarometer survey, this article attempts to test this hypothesis.

\subsection{Data and Variable}

Data for this article comes from Round 6 of the Afrobarometer survey which was conducted in 2014. The Afrobarometer survey is an independent non-partisan research project that measures the social, political and economic atmosphere in Africa (www.afrobarometer.org). It is conducted regularly in 35 African countries. For the present analysis, we used data from Round 6 for Botswana, Namibia and Zambia. The total sample size was 3599 respondents; 1200 respondents each for Botswana and Namibia, and 1199 for Zambia.

\subsection{Dependent Variable}

The survey questioned respondents as to whether or not they had voted in the last election in their country. This information, whether or not they had voted in the last election, is taken as the dependent variable and an indicator to measure the respondents' participation in political activity. For Botswana and Namibia, this question pertains to the elections conducted in 2014 and for Zambia, the election conducted in 2011. There were nine options given for responding to that question and for the analysis, we dichotomised the options into Yes= Voted in the last election and Else $=$ other answers. Table 1 shows the details of respondents who voted in each country's last election.

Table 1 Number of people voted in the last election

\begin{tabular}{lcc}
\hline \multirow{2}{*}{ Country } & \multicolumn{2}{c}{ Voted in the last election } \\
\cline { 2 - 3 } & Yes & Percentage \\
\hline Botswana & 728 & 60.7 \\
Namibia & 779 & 65.2 \\
Zambia & 723 & 60.6 \\
\hline Total & 2230 & 62.2 \\
\hline
\end{tabular}

\subsection{Independent Variables}

The concept of social capital has multiple dimensions; associational membership, civic engagement, trust and social cohesion. For this article, we use data on associational membership as a proxy of social capital. The Afrobarometer survey has collected data on respondents' associational membership. The survey had two questions which specifically asked about the respondents' membership of religious organisations and voluntary/community associations. Five options were given for these questions; Not a Member, Inactive Member, Active Member, Official Leader and Don't Know. We have given the following numerical values to these options; Not a Member=0, Inactive Member=1, Active Member=2, and Official Leader=3. Then we added up the values for the two variables, religious organisations and voluntary/community associations, to create a numerical 
score that represents the respondents' associational membership. A higher score indicates strong participation in religious/voluntary organisations.

Table 2 shows the distribution of respondents by their type of participation in the religious organisations and voluntary/community associations in Botswana, Namibia and Zambia.

Table 2. Type of participation in religious organisation and voluntary/community associations

\begin{tabular}{lllllllllll}
\hline & \multicolumn{3}{c}{ Botswana } & \multicolumn{2}{c}{ Namibia } & \multicolumn{3}{c}{ Zambia } & \multicolumn{3}{c}{ Total } \\
\cline { 2 - 11 } & & $\mathrm{N}$ & $\%$ & $\mathrm{~N}$ & $\%$ & $\mathrm{~N}$ & $\%$ & $\mathrm{~N}$ & $\%$ \\
\cline { 2 - 11 } Religious Group & Not a member & 490 & 40.87 & 652 & 54.56 & 299 & 25.06 & 1441 & 40.2 \\
& Inactive member & 171 & 14.26 & 158 & 13.22 & 143 & 11.99 & 472 & 13.2 \\
& Active member & 500 & 41.7 & 338 & 28.28 & 654 & 54.82 & 1492 & 41.6 \\
& Official leader & 37 & 3.09 & 46 & 3.85 & 94 & 7.88 & 177 & 4.93 \\
\hline \multirow{3}{*}{ Voluntary } & Not a member & 899 & 74.98 & 909 & 76.07 & 769 & 64.46 & 2577 & 71.8 \\
& Inactive member & 93 & 7.76 & 116 & 9.71 & 82 & 6.87 & 291 & 8.11 \\
& Active member & 188 & 15.68 & 141 & 11.8 & 288 & 24.14 & 617 & 17.2 \\
& Official leader & 16 & 1.33 & 28 & 2.34 & 47 & 3.94 & 91 & 2.54 \\
\hline
\end{tabular}

Table 3. Distribution of control variables

\begin{tabular}{llcccccccc}
\hline & & Botswana & \multicolumn{3}{c}{ Namibia } & \multicolumn{3}{c}{ Zambia } & \multicolumn{3}{c}{ Total } \\
\hline \multirow{3}{*}{ Education } & & $\mathrm{N}$ & $\%$ & $\mathrm{~N}$ & $\%$ & $\mathrm{~N}$ & $\%$ & $\mathrm{~N}$ & $\%$ \\
& Low & 411 & 34.3 & 336 & 28.1 & 520 & 43.6 & 1267 & 35.3 \\
& Middle & 635 & 53 & 742 & 62.1 & 634 & 53.1 & 2011 & 56.1 \\
& High & 153 & 12.8 & 117 & 9.8 & 35 & 2.9 & 305 & 8.5 \\
\hline \multirow{3}{*}{ Age } & Young & 235 & 19.6 & 293 & 24.5 & 302 & 25.3 & 830 & 23.1 \\
& Middle & 504 & 42 & 518 & 43.4 & 506 & 42.4 & 1528 & 42.6 \\
& Old & 460 & 38.4 & 384 & 32.1 & 370 & 31 & 1214 & 33.8 \\
\hline \multirow{2}{*}{ Residence } & Rural & 440 & 36.7 & 615 & 51.5 & 676 & 56.7 & 1731 & 48.3 \\
& Urban & 759 & 63.3 & 580 & 48.5 & 517 & 43.3 & 1856 & 51.7 \\
\hline \multirow{2}{*}{ Gender } & Male & 600 & 50 & 595 & 49.8 & 599 & 50.2 & 1794 & 50 \\
& Female & 599 & 50 & 600 & 50.2 & 594 & 49.8 & 1793 & 50 \\
\hline
\end{tabular}

Logistical regression was used to estimate the effect of social capital on voting participation. To control for other socio-demographic factors, we included age, gender, education and place of residence as control variables in the regression model. The survey collected educational qualifications of the respondents in ten categories; however, for the present analysis, we collapsed that into three categories. The new categories created are: Low Education (by combining the categories "No formal schooling", "Informal schooling only", "Some primary schooling" and "Primary school completed"); Middle Education (combining "Some secondary school/high school", "Secondary school completed/high school", "Post-secondary qualifications" and "Not university"); and High Education (combining "Some university", "University completed" and "Post-graduate"). Age of respondents was collapsed into three categories: Young ( $<25$ years); Middle (25-39 years); and Old (more than 40 years).

Table 3 shows the distribution of respondents by age, education, place of residence and gender. We used the statistical analysis environment $\mathrm{R}$ for the analysis (R Core Team, 2014). 
Table 4. Descriptive statistics of variables used in the analysis

\begin{tabular}{|c|c|c|c|c|c|}
\hline & $\mathrm{N}$ & Mean & Std. deviation & Minimum & Maximum \\
\hline Voted in Previous Election & 3587 & 0.62 & 0.49 & 0 & 1 \\
\hline \multicolumn{6}{|l|}{ Associational Membership } \\
\hline Religious Group Membership & 3582 & 1.11 & 1.00 & 0 & 3 \\
\hline $\begin{array}{l}\text { Community } \\
\text { Membership }\end{array}$ & 3576 & 0.50 & 0.86 & 0 & 3 \\
\hline \multicolumn{6}{|l|}{ Demographic Attributes } \\
\hline Education & 3583 & 1.73 & 0.61 & 1 & 3 \\
\hline Gender & 3587 & 1.50 & 0.50 & 1 & 2 \\
\hline Age & 3572 & 40.58 & 62.04 & 18 & 98 \\
\hline Rural/Urban & 3587 & 1.52 & 0.500 & 1 & 2 \\
\hline
\end{tabular}

\section{Results and Discussion}

Table 5 presents the results of the logistic regression model, estimating the effect of social capital on voting participation in Botswana, Namibia and Zambia. The analysis revealed that people's degree of social capital has a positive influence on their voting participation in these countries. The following inferences can be made from the analysis:

1) Social capital has a positive influence on voting participation in the study countries.

2) Respondents belonging to the older age group were more likely to have voted in the most recent elections compared to those in the other age groups.

3) Respondents in the younger age group were least likely to have voted.

4) Respondents with higher social capital were more likely to have voted.

5) Respondents from Namibia and Zambia were more likely to have voted compared to Botswana.

As has been found in a number of earlier studies, social capital has various effects on political engagements in Africa. Some of these effects can be seen on political trust (Kuenzi, 2008), political violence (Bhavnani \& Backer, 2007) and government effectiveness (Widner \& Mundt, 1998). For example, Kuenzi's (2008) study, which examined the influence of social capital on political trust in Nigeria and Ghana, found that organisational membership (as a form of social capital) has a negative association with political trust in Nigeria and a weak positive relationship in Ghana. Furthermore, in a 2007 study, Bhavnani \& Backer looked at the relationship between membership in professional and business associations (as a form of social capital) and political violence, and found that "...membership in professional and business associations is consistently linked with greater levels of political violence, whereas membership in religious groups seems to lessen such conflict" (Bhavnani \& Backer, 2007, p.2). Similarly, Widner \& Mundt's (1998) study explored the relationship between social capital and governmental effectiveness in Botswana and Uganda, finding that there is a weak relationship between social capital and government effectiveness in both Botswana and Uganda.

Our analysis shows that there is a positive relationship between social capital and voting participation in Botswana, Namibia and Zambia. Not only does this add to the knowledge about social capital's influence on political engagement in Africa, but it is also consistent with the prevailing notion in developed democracies that social capital has a positive effect on political participation. However, the effect of social capital on political participation was not found to be commensurate with early studies in Africa which revealed that social capital has an asymmetric effect on other aspects of political engagements such as; political trust, governmental effectiveness, political violence, post-conflict reconstruction and success in business. The results of our study are in agreement with the findings of recent, similar studies in developed democracies that social capital has a positive effect on political participation (Hooghe \& Marien, 2013; LeRoux \& Krawczyk, 2014).

The regression analysis shows that voting participation significantly varies between these three countries. It became evident from the analysis that respondents from Namibia and Zambia were more likely to have voted than those from Botswana. Compared to Botswana, people in Namibia were twice as likely to have voted in an election. However, this finding contrasts with the real election data provided by the Election Guide website (see 
http://www.electionguide.org/), which uses actual election data to show that voter turnout in Botswana (85\%) and Namibia (72\%) was higher than that of Zambia (53\%).

Table 5. Logistic regression model assessing effect of social capital on voting participation in three African democracies (Dependent variable Voted $=1$ )

\begin{tabular}{lll}
\hline & Odds Ratio & $95 \%$ CI lower-upper \\
\hline Gender & Ref & \\
Male & 0.86 & $0.70-1.06$ \\
Female & & \\
Residence & Ref & \\
Urban & 1.19 & $0.96-1.48$ \\
Rural & & \\
Age & Ref & \\
Middle Aged & $1.80^{* * *}$ & $1.39-2.34$ \\
Old Aged & $0.093^{* * *}$ & $0.07-0.12$ \\
Young Aged & & \\
Education & Ref & $0.84-1.92$ \\
High & 1.27 & $0.83-1.73$ \\
Low & 1.19 & \\
Middle & & $1.54-2.58$ \\
Country & Ref & $1.02-1.70$ \\
Botswana & $1.99^{* * *}$ & \\
Namibia & $1.31^{*}$ & $1.19-1.39$ \\
Zambia & & \\
Social Capital & $1.28^{* * *}$ & \\
Social Capital & 0.348 & \\
\hline Nagelkerke R2: & 2238.1 & \\
AIC: & 2218.09 & \\
$-2 *$ LL & & \\
\hline
\end{tabular}

Not surprisingly, different social demographic factors also appear to influence voting participation. It was found that people belonging to the older age group are more likely to vote in elections than people in the younger and middle age group. The reason for higher voting participation within the older age group compared to other age groupings in all three countries might be because of the elevated social status of older people across African cultures, which portrays them as portals of knowledge (for a brief analysis of voting participation among different age groups in Zambia, see Bwalya \& Sukumar (2016)). Older people in traditional African cultures are quite often the go-to people for advice not only pertaining to cultural matters but political advice as well. It appears that to keep up and maintain their higher status in their communities, older people might try to lead the forefront of political activities. This we argue, might be an innate calling emanating from millennia-old cultural, traditional and social psyches, which drives these individuals to want to be in the know. The findings on age wise variation in voting participation between different age groups are in line with other studies, including those from developed democracies (e.g., Norris, 2002) as well as recent studies from developing African democracies such as in the case of Zambia (on this distinction, see Bratton (1999)).

This analysis finds that level of education attained does not have any significant association with voting participation. This is quite interesting as it contradicts several studies including Verba et al. (1995), who point to the fact that when an individual's educational levels increase, the skills and resources that promote higher levels 
of political participation also increase. The reason for the ineffectiveness of educational attainment on voting participation in Africa, especially in the three study countries, might be due more to the determining influence of ethnocultural identities on political decisions than socio-economic factors in Africa (for an analysis on ethnopolitical dynamics in Africa, see e.g. Eifert et al. (2010)). The accumulation and possession of cultural capital within African societies tend to dictate how an individual, despite their level of education attainment, would behave in the political process. This ultimately becomes an unthinking reaction that leads people to engagement and participation in political affairs such as voting participation (Bwalya 2017).

Also, interestingly, we found that respondents with higher levels of social capital in all three countries were more likely to participate in elections. This confirms Putnam's (2001) finding from his classic study "Bowling Alone: The Collapse and Revival of the America Community", which revealed that individuals' social capital has a positive effect on their political participation.

\section{Conclusion}

This article raised one central question: to what extent does people's social capital influence their voting participation in developing democracies of Africa? The answer, based on analysis of Round 6 of the Afrobarometer survey, revealed that social capital has a positive influence on people's voting participation in three democratically developing countries of Africa, viz. Botswana, Namibia and Zambia.

The results of this article pertain to an important current debate, that is, the relationship between social capital and political participation. The key finding is that social capital influences voting participation which is in support of Putnam's conceptualisation of social capital as an important variable in encouraging political participation.

When socio-demographic factors such as age and education were taken into consideration, it was found that voting participation is not significantly influenced by these factors in developing African democracies. Interestingly, when compared to those in the middle and young age categories, people belonging to the older age group are more likely to participate in elections. This finding meshes well with other studies from developed democracies which point to the fact that older people with high social capital are more likely to engage in political participation. Lastly, of all the three age categories, respondents in the young age group were least likely to have voted. Education, contrary to the suggestions established by many earlier studies, was found to have no significant influence on voting participation in Botswana, Namibia and Zambia.

\section{References}

Addison, T., \& Baliamoune-Lutz, M. (2004, 4-5 June). The role of social capital in post-conflict reconstruction. Paper presented at the UNU-WIDER conference on 'Making Peace Work', Helsinki.

Anderson, L. E. (2010). Social Capital in Developing Democracies: Nicaragua and Argentina. Cambridge University Press.

Atkinson, M. D., \& Fowler, A. (2014). Social Capital and Voter Turnout: Evidence from Saint's Day Fiestas in Mexico. British Journal of political science, 44(01), 41-59. http://dx.doi.org/10.1017/s0007123412000713

Ayala, L. J. (2016). Trained for Democracy: The Differing Effects of Voluntary and Involuntary Organizations on Political Participation. Political Research Quarterly, 53(1), 99-115. http://dx.doi.org/10.1177/106591290005300105

Bartlett, D. M. C. (2000). Civil society and democracy: A Zambian case study. Journal of Southern African Studies, 26(3), 429-446. http://dx.doi.org/10.1080/030570700750019655

Berinsky, A. J. (2016). The Perverse Consequences of Electoral Reform in the United States. American Politics Research, 33(4), 471-491. http://dx.doi.org/10.1177/1532673x04269419

Bhavnani, R., \& Backer, D. (2007). Social capital and political violence in Sub-Saharan Africa. Paper presented at the September annual meeting of the American Political Science Association, Chicago.

Blais, A. (2006). What affects voter turnout? Annual Review of Political Science, 9(1), 111-125. http://dx.doi.org/10.1146/annurev.polisci.9.070204.105121

Booth, J. A., \& Richard, P. B. (1998). Civil Society, Political Capital, and Democratization in Central America. The Journal of Politics, 60(3), 780-800. http://dx.doi.org/10.2307/2647648

Bourdieu, P. (1986). The forms of capital. In J. G. Richardson (Ed.), Handbook of Theory and Research for the Sociology of Education (pp. 241-258). New York: Greenwood Press. 
Bratton, M. (1999). Political participation in a new democracy: Institutional considerations from Zambia. Comparative Political Studies, 32(5), 549-588. http://dx.doi.org/10.1177/0010414099032005002

Bwalya, J. C. (2017). Chinese Investment and Ethno-Political Dynamics in Zambia: A Study of the Patriotic Front Members Experiences and Perception. (PhD thesis), University College Dublin, Ireland.

Bwalya, J. C., \& Sukumar, P. (2016). Gender and Voting Participation in Africa: The Case of Zambia. International Journal of Social Science and Humanities Research, 4(3), 425-435.

Coleman, J. S. (1988). Social capital in the creation of human capital. American journal of sociology, 94, S95-S120.

Düsing, S. (2002). Traditional leadership and democratisation in Southern Africa: A comparative study of Botswana, Namibia, and Southern Africa. LIT Verlag Münster.

Edlin, A., Gelman, A., \& Kaplan, N. (2007). Voting as a rational choice: Why and how people vote to improve the well-being of others. Rationality and society, 19(3), 293-314. http://dx.doi.org/10.1177/1043463107077384

Eifert, B., Miguel, E., \& Posner, D. N. (2010). Political Competition and Ethnic Identification in Africa. American Journal of Political Science, 54(2), 494-510. http://dx.doi.org/10.1111/j.1540-5907.2010.00443.x

Fafchamps, M., \& Minten, B. (2001). Property Rights in a Flea Market Economy. Economic Development and Cultural Change, 49(2), 229-267. http://dx.doi.org/10.1086/452501

Fiorina, M. P. (1990). Information and Rationality in Elections. In J. A. Ferejohn \& J. H. Kuklinski (Eds.), Information and Democratic Processes. Champaign: University of Illinois Press.

Fowler, J. H. (2005). Turnout in a Small World. In A. Zuckerman (Ed.), Social Logic of Politics (pp. 269-287). Philadelphia: Temple University Press.

Fowler, J. H. (2006). Altruism and Turnout. The Journal of Politics, 68(3), 674-683. http://dx.doi.org/10.1111/j.1468-2508.2006.00453.x

Friede, H., \& Steel, R. (1986). Traditional Wooden Drum Bellows of South-Western Africa. The South African Archaeological Bulletin, 41(143), 12. http://dx.doi.org/10.2307/3887712

Fukuyama, F. (1995). Trust: The social virtues and the creation of prosperity. New York: Free Press Paperbacks.

Gerber, A. S., Green, D. P., \& Larimer, C. W. (2008). Social Pressure and Voter Turnout: Evidence from a Large-Scale Field Experiment. American Political Science Review, 102(01), 33-48. http://dx.doi.org/10.1017/s000305540808009x

Geys, B. (2006). Explaining voter turnout: A review of aggregate-level research. Electoral Studies, 25(4), 637663. http://dx.doi.org/10.1016/j.electstud.2005.09.002

Goldsmith, A. A. (2001). Foreign Aid and Statehood in Africa. International Organization, 55(1), 123-148. http://dx.doi.org/10.1162/002081801551432

Hooghe, M., \& Marien, S. (2013). A comparative analysis of the relation between political trust and forms of political participation in Europe. European Societies, 15(1), 131-152. http://dx.doi.org/10.1080/14616696.2012.692807

Jager, N. D. (2014). Why elections in Botswana and South Africa can be 'free' but not 'fair'. Retrieved from http://democracyinafrica.org/elections-bostwana-south-africa-can-free-fair/

Klesner, J. L. (2007). Social Capital and Political Participation in Latin America: Evidence from Argentina, Chile, Mexico, and Peru. Latin American research review, 42(2), 1-32. http://dx.doi.org/10.1353/lar.2007.0022

Krishna, A. (2016). Enhancing Political Participation in Democracies. Comparative Political Studies, 35(4), 437-460. http://dx.doi.org/10.1177/0010414002035004003

Kuenzi, M. T. (2008). Social capital and political trust in West Africa. Afro barometer Working paper, 96, 1-32.

La Due Lake, R., \& Huckfeldt, R. (1998). Social Capital, Social Networks, and Political Participation. Political Psychology, 19(3), 567-584. http://dx.doi.org/10.1111/0162-895x.00118 
Lee, A.-R., \& Glasure, Y. U. (2007). Social Capital and Political Participation in South Korea. Asian Affairs: An American Review, 34(2), 101-118. http://dx.doi.org/10.3200/aafs.34.2.101-118

LeRoux, K., \& Krawczyk, K. (2014). Can Nonprofit Organizations Increase Voter Turnout? Findings From an Agency-Based Voter Mobilization Experiment. Nonprofit and Voluntary Sector Quarterly, 43(2), 272-292. http://dx.doi.org/10.1177/0899764012459909

Lewis, S. R. (2010). Explaining Botswana's Success: The Importance of Culture. Carleton College, nd.

Lindberg, S. I. (2005). Consequences of electoral systems in Africa: a preliminary inquiry. Electoral Studies, 24(1), 41-64. http://dx.doi.org/10.1016/j.electstud.2004.02.006

Mayer, N. (2003). Democracy in France: Do associations matter. In D. Stolle, \& M. Hooghe (Eds.), Generating social capital: Civil society and institutions in comparative perspective (pp. 43-66). New York: Palgrave Macmillan.

Miller, M. K. (2001, August 30-September 2). Organized Groups and Political Participation: Varieties of Social Influence. Paper presented at the Annual Meeting of the American Political Science Association, San Francisco, CA.

Moyser, G., \& Parry, G. (1997). Voluntary associations and democratic participation in Britain. In J. W. van Deth (Ed.), Private Groups and Public Life: Social Participation and Political Involvement in Representative Democracies (pp. 24-46). London: Routledge.

Mutz, D. C. (2002). The Consequences of Cross-Cutting Networks for Political Participation. American Journal of Political Science, 46(4), 838. http://dx.doi.org/10.2307/3088437

Norris, P. (2002). Democratic Phoenix: Reinventing Political Activism. Cambridge: Cambridge University Press.

Nygård, M., Nyqvist, F., Steenbeek, W., \& Jakobsson, G. (2015). Does social capital enhance political participation of older adults?: A multi-level analysis of older Finns and Swedes. Journal of International and Comparative Social Policy, 31(3), 234-254. http://dx.doi.org/10.1080/21699763.2015.1069207

Paxton, P. (2002). Social Capital and Democracy: An Interdependent Relationship. American Sociological Review, 67(2), 254. http://dx.doi.org/10.2307/3088895

Portes, A. (1998). Social capital: Its origins and applications in modern sociology. Annual review of sociology, 24(1), 1-24. http://dx.doi.org/10.1146/annurev.soc.24.1.1

Putnam, R. D. (1995a). Bowling alone, revisited. Responsive community, 5(2), 18-33.

Putnam, R. D. (1995b). Bowling Alone: America's Declining Social Capital. Journal of Democracy, 6(1), 65-78. http://dx.doi.org/10.1353/jod.1995.0002

Putnam, R. D. (2001). Bowling alone: The collapse and revival of American community. New York: Simon and Schuster.

Putnam, R. D., Leonardi, R., \& Nanetti, R. Y. (1993). Making democracy work: Civic traditions in modern Italy. Princeton: Princeton University Press.

R Core Team. (2014). R: A language and environment for statistical computing. Vienna, Austria: R Foundation for Statistical Computing; 2014. Vienna; Austria.

Riker, W. H., \& Ordeshook, P. C. (1968). A Theory of the Calculus of Voting. American Political Science Review, 62(01), 25-42. http://dx.doi.org/10.2307/1953324

Rotemberg, J. J. (2009). Attitude-dependent altruism, turnout and voting. Public Choice, 140(1-2), 223-244. http://dx.doi.org/10.1007/s11127-009-9422-2

Seligson, A. L. (1999). Civic association and democratic participation in Central America: a test of the Putnam thesis. Comparative Political Studies, 32(3), 342-362.

Stolle, D. (1998). Bowling together, bowling alone: The development of generalized trust in voluntary associations. Political Psychology, 497-525.

Stolle, D., \& Rochon, T. R. (2016). Are All Associations Alike?: Member diversity, associational type, and the creation of social capital. American Behavioral Scientist, 42(1), 47-65. http://dx.doi.org/10.1177/0002764298042001005

Taylor, S. D. (2006). Culture and customs of Zambia. Westport: Greenwood Publishing Group. 
Verba, S., Schlozman, K. L., \& Brady, H. E. (1995). Voice and equality: Civic voluntarism in American politics. Cambridge: Harvard University Press.

Widner, J., \& Mundt, A. (1998). Researching social capital in Africa. Africa, 68(1), 1-24.

\section{Copyrights}

Copyright for this article is retained by the author(s), with first publication rights granted to the journal.

This is an open-access article distributed under the terms and conditions of the Creative Commons Attribution license (http://creativecommons.org/licenses/by/4.0/). 